\title{
Does Flypaper Effect Exist? New Evidence from Turkish Municipalities'
}

Yasin ACAR (https://orcid.org/0000-0002-0847-1902), Department of Public Finance, Bilecik Şeyh Edebali University, Turkey; e-mail: yasinacardr@gmail.com

\section{Sinek Kâğıdı Etkisi Türkiye'de Geçerli midir? Belediyeler Üzerine Bir Çalışma ${ }^{2}$}

\begin{abstract}
In this paper, we investigate the phenomenon of flypaper effect and its relation to the local tax effort, by using a new and detailed panel data set that consist of all province and district municipalities' fiscal data in Turkey between 1997 and 2005. We use fixed effects and dynamic panel data specific GMM estimators to obtain the results. We provide new evidence using an advanced technique which is firstly used to uncover flypaper effect in Turkey. According to our estimations, the flypaper effect does exist for the Turkish municipalities. This result is robust to various model specifications and econometric techniques. Turkish municipalities also experience substitution effect of unconditional grants on the revenue collection efforts.
\end{abstract}

Keywords

: $\quad$ Flypaper Effect, Intergovernmental Transfers, Fiscal Federalism, Turkish Municipalities, GMM Estimation.

JEL Classification Codes : $\quad$ H30, H70, H72, H77.

\section{Öz}

Bu makalede, 1997-2005 yılları arasında Türkiye'deki tüm il ve ilçe belediyelerinin mali verilerini içeren yeni ve detaylı panel veri seti kullanılarak sinek kâğıdı etkisi ve onun yerelde vergi gayreti ile ilişkisi araştırılmıştır. Sabit etki ve dinamik panel veri GMM tahmin yöntemlerinden faydalanarak sinek kâğıdı etkininin varlığı test edilmiştir. Tahmin sonuçlarına göre, Türkiye'de belediyelerde sinek kâğıdı etkisi varlığı ortaya konulmuştur. Bu sonuç, çeşitli model ve ekonometrik tekniklerle desteklenmiştir. Ayrıca, şartsız olarak merkezi yönetimden belediyelere verilen mali transferlerin yerelde gelir toplama gayreti üzerinde ikame etkisinin olduğu görülmektedir.

Anahtar Sözcükler $\quad$ : Sinek Kağıdı Etkisi, Mali Transferler, Mali Federalizm, Belediyeler, GMM.

1 This article is derived from author's dissertation called "Essays on Political Economy in Turkey" which was completed in the Department of Economics, University of Warwick in 2015.

2 Bu makale, yazarın, 2015 yllında İngiltere Warwick Üniversitesi Ekonomi Bölümünde tamamladığ " Essays on Political Economy in Turkey" başlıkl doktora tezinden üretilmiştir. 


\section{Introduction}

The debate about whether intergovernmental grants and local private income have similar effects on local expenditures has found an important place among researchers. In local public finance literature, this phenomenon has been called as the flypaper effect, which is a term derived from the statement for "money sticks where it hits". The flypaper effect predicts that non-matching grants (revenue-sharing type) stimulate much more local spending than does income going to private citizens within the community. It can also be explained that money received in the public sector is more likely to remain in the public sector, whereas money received in the private sector is more likely to remain in the private sector (Fisher, 1982). The reason of this fact is that politicians at local level do not tend to be cutting taxes when the local government receives revenue-sharing monies.

Trying to model how receiving governments respond to grants need much more than an understanding of the economic equivalences between different grants formulas. Actual problem is how governments determine their spending and revenue decisions. The decisions are the result of some kind of political process rather than simply economic. As such, a model that tries to explain governments' responses to grants is only as good as its ability to model the underlying political process that generates their responses. Today, local governments and political forces have become numerous with growing communities and moved beyond the simplest one-person, one-vote direct democracies of the small village. Therefore, it will be tough to capture all the political distinctions that take place in large communities and provincial governments.

Nevertheless, most of economists have essentially chosen median voter model that is commonly used to develop empirical models of local (state or provincial) governments' decisions on spending, revenues, and grants transferred by upper-tier or central government. The main assumption of the model is that a government's spending and revenue decisions are those that match the preferences of the median voter in its jurisdiction. So, median voter is the one whose preferences on spending and revenues lie in the middle of the preferences.

Several research theories have endeavoured to explain the flypaper effect phenomenon. There are two main discussions competing with each other. First, flypaper effect is caused by a fiscal illusion. Second, the reason of the effect is bureaucrats. We will give a brief explanation about these two models below.

\subsection{Fiscal Illusion}

In this view, the flypaper effect is the outcome of voter-taxpayer ignorance of fiscal illusion. Fiscal illusion literature argues that some features of the tax structure influence voter's perceptions about how much they are financing the cost of public goods. Fiscal illusion suggests that when government revenues are not completely perceived by taxpayers, then the cost of public goods is seen less expensive than it actually is. The demand for government expenditures increases since taxpayers benefit from government expenditures 
from these unobserved revenues. As a result, politicians have an incentive to expand the size of government.

\subsection{The Bureaucratic Model}

According to these models, bureaucrats or local politicians are seen as exercising monopoly control over publicly produced goods and services. They use this power to compel elected officials into approving larger budgets at higher cost per unit than would otherwise occur, to improve their prestige and power (Niskanen, 1968; Wyckoff, 1988). The flypaper effect might occur in the bureaucratic model since bureaucrats have much more knowledge regarding with grants and budget. This superior information enables him to obtain a budget in excess of that desired by the median voter (Sagbas \& Saruç, 2004). It is argued that the bureaucrats, who act strategically, disclose asymmetric information, responds the budget cuts by cutting the most popular programs first, and magnifies all budget requests (Schwallie, 1989). There are many other models and theories attempting to explain the reason of flypaper effect in public finance literature ${ }^{3}$. The main inference of the bureaucratic model explanation of the flypaper effect is that local authorities exert lesser local tax effort because managers in local depend on grants to finance their spending.

\section{Literature Review}

There have been numerous studies on flypaper effect and whether intergovernmental transfers stimulate or substitute local tax effort. Gramlich et al. (1973) pioneered one of the first discussions on the expenditure effects of intergovernmental transfers. They have categorized the intergovernmental grants as;

- Open-end matching grants, where the higher level of government finance some portion of the cost of certain expenditures of lower level of government. This obviously reduces the price of services provided by local government.

- Closed-end lump sum transfers, where the higher level of government transfers a fixed amount of money to a lower level of government without dictating any aim on the use of money or changing any relative prices. This may be based on any allocation formula such as population criteria; Turkish local government system has this type of transfers, which is also called revenue-sharing programmes.

- Closed-end categorical grants, where the higher level of government transfers a limited amount of money to be used for a particular programme started by lower 
level of government. This type of grants may be thought a mixed of first two categorizes (price of the programme is lowered, but the size of the grant is limited).

According to the authors expenditure effect should be larger for open-end matching grants and smaller for closed-end lump-sum transfers, while the expenditure effect of closedend categorical grants should be between those two effects. Hence, lump-sum grants should have only income effect, whereas matching grants should also have substitution (price) effect (Bailey \& Connolly, 1998). However, recent literature finds that lump-sum grants should also have price effect since the grants help the local authority to reduce tax rates even if they provide the same level of local public goods. Marginal costs of public funds are lower, which means that the effective price of providing the public goods is also reduced.

Gramlich et al. (1973) found that lump-sum transfers have larger effect on government spending than equivalent increase in private income. According to their estimation, each dollar of private income increases state and local expenditures by only 10 cents in the United States.

The issue of flypaper effect has been hugely examined in the empirical literature beside theoretical studies (Acosta, 2010; Case et al., 1993; Knight, 2002; Turnbull, 1998; Worthington \& Dollery, 1999). Most of these studies tend to focus on industrialised countries. Pevcin (2011) examines the expenditure and tax effort effect of municipal transfers in Slovenia and the empirical analysis shows that transfer revenues (grants) have absolutely and relatively larger effect on municipal expenditures than equivalent increase in income. He also finds that substitution effect exists meaning transfer revenues have negative impact on municipal tax effort.

By exploiting a reform of the fiscal equalization system in the Netherlands Allers and Vermeulen ( 2016) show that the resulting change in grants to municipalities was fully capitalized into local house prices. They find that only a small fraction was passed on to residents through property taxes. They also find that a strong flypaper effect exists and there is full capitalization of exogenous grant changes.

There are also studies that empirically test flypaper effect and find no evidence. For example Worthington and Dollery (1999) investigate the flypaper effect for Australian local governments and could find no effect and interestingly their estimates show that intergovernmental transfers have statistically significant negative effect on local government expenditure. Becker (1996) reveals that flypaper effect is in fact an illusion since the results are very sensitive to estimation technique and inappropriate functional form of estimation might generate different conclusions.

Sagbas and Saruc, 2008; Sagbas and Saruç (2004) examines whether grants cause the flypaper effect in the face of linear budget constraint in Turkey. They argue that the flypaper effect exists and could be explained by the bureaucratic model. In other study where the same authors contributed, they state that local tax effort is affected by the substitution and 
stimulative effects of grants on local expenditure in addition to the variance in the flypaper effect.

Our paper on flypaper effect analysis contributes to the literature in Turkey in two ways. First, we use GMM, which is a more advanced method, considering there might be two-way causation in grants and income. It enables us to obtain more robust results compared to previous studies on Turkey aforementioned above. This method also provides us more reliable estimates since the difference in magnitude between grant and income coefficients are close to each other, but statistically not equal based upon T-test. In previous studies there are huge difference on those coefficients which is most like due to OLS method used and not considering endogeneity.

\section{Local Governments in Turkey}

Turkey is divided into provinces on the basis of geographical situation, economic conditions and public service requirements; provinces are further divided into lower level administrative entities according to their population sizes, such as districts or townships. In each district and township there are urban settlements, which are called municipalities. As of 2012, there are 81 provinces and around 2950 municipalities in Turkey. Table 1 shows the number of municipalities by their type in Turkey. According to table 1, Turkey have 16 Metropolitan, 143 metropolitan districts, 65 provincial, 749 districts and 1977 town municipalities. About two thirds of all municipalities are formed by township municipalities, where more than 2000 inhabitants live, according to the latest population census. Each municipality is established to meet the common needs of inhabitants living within the municipal borders. The mayor and municipal council, which is the decision-making organ of the municipality, are acceded in the elections.

Table: 1

Numbers of Municipalities by Type

\begin{tabular}{|l|c|}
\hline Municipalities & Count \\
\hline Metropolitan Municipality & 16 \\
\hline Metropolitan District Municipality & 143 \\
\hline Provincial Municipality & 65 \\
\hline District Municipality & 749 \\
\hline Town Municipality & 1977 \\
\hline Total & 2950 \\
\hline
\end{tabular}

Source: Ministry of Interior, General Directorate of Local Governments.

The head of the municipal administration is the mayor and he/she represents its legal personality. The mayor is elected by the public for a period of five years. The municipal councils are also elected for five years and vary in size according to each town`s population. They decide issues such as budgets, housing plans, reconstruction programmes, tax rates and fees which are essential for municipal services.

\subsection{Revenues}

The revenues of municipalities comprise their own revenues, shares from state tax revenues, state aid and other revenues. About half of the total revenues come from the share 
of state tax revenues. Table 2 demonstrates the main components of the municipal revenue, as of 2010, in Turkey. It is clearly seen from table 2 that shares received from the General Budget Tax Revenues forms the main income for the municipalities in Turkey.

Table: 2

Municipal Revenues

\begin{tabular}{|l|r|r|}
\hline Types of Revenues & Thousand TL & \% \\
\hline Shares Received from the General Budget Tax Revenues & 17.333 .265 & 50,6 \\
\hline Tax Revenues & 5.854 .566 & 17,1 \\
\hline Enterprise and Ownership Revenues & 4.824 .058 & 14,1 \\
\hline Interests, Shares and Fines & 3.075 .067 & 9,0 \\
\hline Capital Revenues & 2.533 .815 & 7,4 \\
\hline Other Revenues & 613.092 & 1,8 \\
\hline Total Revenues & $\mathbf{3 4 . 2 3 3 . 8 6 3}$ & $\mathbf{1 0 0}$ \\
\hline
\end{tabular}

Source: General Activity Report of Local Authorities, 2010.

$39 \%$ of total municipal revenues come from revenues raised locally although the tax rates and fees are almost exclusively centrally determined.

Municipalities' revenues are derived from different sources and can be divided into three main groups; tax revenues, revenues other than taxes and aid and funds. Tax revenues cover the shares received from general budget tax revenues, municipal taxes and municipal duties. Municipal taxes come directly from several sources. These taxes are mainly property taxes, environment cleanliness taxes and other municipal taxes including fire insurance taxes, and advertisement and notification taxes. In addition, some other own resources, called duties, are levied from local residents such as street lightning duty, work at the weekend and on holiday duty, and mineral water duty.

\subsection{Central Government Transfers}

Central government transfers to municipalities account for about $2 \%$ of GNP and correspond to around 50\% of the municipalities' revenues. The transfers are made through three mechanisms: $6 \%$ of national taxes are allocated to the municipalities according to population levels (55\% of transfers); $4.1 \%$ of taxes collected within the province of a metropolitan municipality are transferred back to the metropolitan municipality (30\% of transfers); and there are transfers through special government programs (15\% of transfers).

The official budget size of municipal governments is about 4-6\% of GDP, which is on par with many European countries. The largest share of revenues is made up of transfers (grants) from the central government, while property taxes are one of a few locally determined sources of revenues. Transfers are largely determined by population and whether a municipality is a district or province centre (Worldbank, 2004). The central government has left local public services and urban development (building permits) as the responsibility of the municipal mayor.

\section{Data, Model Specification and Estimation}

We follow similar model used by Sagbas and Saruç (2004) and Cárdenas and Sharma (2011). We use a panel data set of 838 Turkish municipalities between 1997 and 2005 for 
the period. Since we do not have a fiscal data for the year of 1998, our data set jumps from 1997 to 1999. The source for our data is Turkish Statistical Institute (TUIK). Data is well documented and detailed. Analysis stops in 2005 since there is no disaggregated data in later years. We include province (il) and district (ilce) municipalities but not town (belde) municipalities to our analysis we do not have enough data for towns. Out of 838 municipalities, the number of province municipalities is 59 and the remaining 739 are district municipalities. We obtain the fiscal data (grant, revenue, expenditure, etc) for municipalities from the Final Accounts provided by municipalities at the end of each year. All economic variables are deflated using price-index taken from State Planning Organization (DPT) of Turkey. Therefore grant, income and expenditure variables are in real terms in all specifications.

The summary statistics are presented in Table 3.

Table: 3

\section{Summary Statistics}

\begin{tabular}{|c|c|c|c|c|}
\hline VARIABLES & Mean & Std.Dev & Min & $\operatorname{Max}$ \\
\hline Grant & 10,75 & 6,702 & 0,101 & 148,7 \\
\hline Income & 11,81 & 12,13 & 0,103 & 379,7 \\
\hline Expend & 24,11 & 21,58 & 0,112 & 645,6 \\
\hline Population & 46.289 & 104.864 & 754 & 990.073 \\
\hline Popover18 & 52,98 & 16,17 & 7,606 & 229,0 \\
\hline
\end{tabular}

The equation we estimate is as follows:

$$
E x_{i t}=\alpha_{0}+\beta_{0} \text { Grants }_{i t}+\beta_{1} \text { Income }_{i t}+Z_{i t} \gamma+\xi_{i t}
$$

where;

$E x_{i t}=$ Per capita expenditure in 1998 Turkish liras of municipality $i$ in year $t$.

Income $_{i t}=$ Per capita own source income 1998 Turkish liras of municipality $i$ in year $t$

Grants $_{i t}=$ Per capita unconditional grants in 1998 Turkish liras of municipality $i$ in year $t$

$Z_{i t}=$ Social Characteristics of municipality $i$ in year $t$.

In this study, we follow the conventional approach (Courant et al., 1978) where the flypaper effect is explored in the face of linear budget constraint because grants from central government are allocated without any matching requirements in Turkey. 
In order for us to argue flypaper effect does exist, then the magnitude of the coefficient of grants variable must be bigger than the coefficient of income variable in equation (1), that is $\beta_{0}>\beta_{1}$. Moreover, we could say that unconditional grants have a stimulation effect on the local tax effort conditional on $\beta_{0}>1$, while if $\beta_{0}<1$, then it generates a substitution effect, which is likely to reduce the local tax effort.

We begin estimating the equation (1) in the first column and add one variable at a time in order to check if the existence of the fly paper effect is sensitive to the included variables. That is, we first estimate equation (1) without controlling for the municipality's characteristics, and later we add these characteristics one by one. Table 4 presents the results from these estimations.

Table: 4

OLS Fixed Effects Estimation Results, Testing for Flypaper (Turkish Lira per capita, dependent variable is expenditure per capita)

\begin{tabular}{|c|c|c|c|c|}
\hline VARIABLES & $\begin{array}{c}\text { Expenditure } \\
\text { I }\end{array}$ & $\begin{array}{c}\text { Expenditure } \\
\text { II }\end{array}$ & $\begin{array}{c}\text { Expenditure } \\
\text { III }\end{array}$ & $\begin{array}{c}\text { Expenditure } \\
\text { IV }\end{array}$ \\
\hline Grants & $\begin{array}{l}1,052 * * * \\
(0,095)\end{array}$ & $\begin{array}{l}1,044 * * * \\
(0,098)\end{array}$ & $\begin{array}{l}1,037 * * * \\
(0,123)\end{array}$ & $\begin{array}{l}1,011 * * * \\
(0,123)\end{array}$ \\
\hline Income & $\begin{array}{l}0,921 * * * \\
(0,048)\end{array}$ & $\begin{array}{l}0,923^{* * * *} \\
(0,048)\end{array}$ & $\begin{array}{l}0,916 * * * \\
(0,049)\end{array}$ & $\begin{array}{l}0,899 * * * \\
(0,054)\end{array}$ \\
\hline Population & & $\begin{array}{l}-0,000 * * * \\
(0,000)\end{array}$ & $\begin{array}{l}-0,000 \text { **** } \\
(0,000)\end{array}$ & $\begin{array}{l}-0,000 * * * \\
(0,000)\end{array}$ \\
\hline Popover18 & & & $\begin{array}{l}0,027 \\
(0,034)\end{array}$ & $\begin{array}{l}0,026 \\
(0,030)\end{array}$ \\
\hline Lag expenditure & & & & $\begin{array}{l}0,104 * * \\
(0,048)\end{array}$ \\
\hline Constant & $\begin{array}{l}-6,382^{\text {**** }} \\
(1,417)\end{array}$ & $\begin{array}{l}-4,876^{* * *} \\
(1,709)\end{array}$ & $\begin{array}{l}-6,039^{* * * *} \\
(1,232)\end{array}$ & $\begin{array}{l}-9,412 * * * \\
(2,217)\end{array}$ \\
\hline Observations & 6.958 & 6.958 & 6.559 & 6.437 \\
\hline Year dummies & Yes & Yes & Yes & Yes \\
\hline $\begin{array}{l}\text { Municipality } \\
\text { Fixed effects }\end{array}$ & Yes & Yes & Yes & Yes \\
\hline $\begin{array}{l}\text { R-squared } \\
\text { F statistic }\end{array}$ & $\begin{array}{l}0,674 \\
F(9,80)= \\
373,43\end{array}$ & $\begin{array}{l}0,674 \\
F(10,80)= \\
326,15\end{array}$ & $\begin{array}{l}0,726 \\
F(11,80)= \\
334,81\end{array}$ & $\begin{array}{l}0,766 \\
F(12,80)= \\
297,85\end{array}$ \\
\hline
\end{tabular}

Notes: This table presents OLS regressions with expenditure per capita as dependent variable. The independent variables of interest are grant and income variables.

Significant levels $* * * p<0.01, * * p<0.05, * p<0.1$, Figure in parenthesis are heteroskedasticity corrected standard errors.

As we see, the baseline model (column I) shows the existence of flypaper effect and grants also have stimulation effect on revenue collection effort. Additional 1 Turkish Lira (TL) grant increase leads municipal expenditure by more than $1 \mathrm{TL}$. Table 1 also suggest that revenue sharing (grant) stimulates local expenditure more than municipal local budget tax revenues (a proxy for local income). The same argument holds when we control for the population, population over 18 years old and lag expenditure (columns II, III, IV respectively). All specifications include time and municipality fixed effects in order to control for time invariant, municipality specific preferences for public spending, such as geography. 
Since we have a lagged dependent variable in our specification (IV) that makes the equation dynamic panel data, it may not be efficient in terms of econometric issues. Therefore, we need to make sure that the previous findings are efficient and robust in dynamic panel data models. We estimate the following generalized equation:

$$
E x_{i t}=\alpha_{0}+\beta_{0} E_{i t-1}+\beta_{1} \text { Grants }_{i t}+\beta_{2} \text { Income }_{i t}+Z_{i t} \gamma+\xi_{i t}
$$

where:

$E x_{i t-1}=$ The per capita expenditure in 1998 Turkish Liras of municipality $i$ in year $t-1$ follows;

Why we adopt dynamic panel data estimation technique can be summarised as

First issue is that the variables Grants, Income are potentially endogenous in equation (2) due to two-way causality. In other words, not only Grants, Income impact expenditure, but they are affected by expenditure at the same. If there is an increase in expenditure, it is most likely to stimulate revenue in the municipality. An increase in expenditure is likely to influence unconditional grants since both of them might be correlated with the unobservable such as performance or state of the economy, political cycle etc. If we want to express it more technically, it is said that the regressors are likely to be correlated with the error term.

Second problem arises due to the time-invariant municipality characteristics (fixed effects). Geographic factors, institutions and demographics of districts might be correlated with the explanatory variables. The error term in equation (2) accommodates municipality fixed effects, $u_{i}$, and the observation-specific errors, $\varepsilon_{i t}$ :

$$
\xi_{i t}=u_{i}+\varepsilon_{i t}
$$

Third issue is the fact of autocorrelation that is emerged with the inclusion of the lagged-dependent variable, $E x_{i t-1}$.

Since we have a panel dataset that consists of a short time dimension $(\mathrm{T}=8)$ and large municipality dimension $(\mathrm{N}=841)$.

Problem 1 and 2 above can be solved by using fixed-effects instrumental variables estimation (so called two-stage least squares or 2SLS). However, we are not able to implement this technique due to the lack of exogenous instruments to identify the endogenous variables. Therefore, we use Arellano-Bond difference GMM (Generalized Method of Moments) estimator Arellano and Bond (1991), which is first proposed by HoltzEakin et al. (1988). It enables us to use the lagged levels of the endogenous regressors as 
instruments. Endogenous variables become pre-determined and, therefore not correlated with the error term in equation (2).

We cope with the problem of fixed effects by using the difference GMM estimator after transforming equation (2) into;

$$
\Delta E x_{i t}=\Delta \beta_{0} E_{i t-1}+\beta_{1} \Delta \text { Grants }_{i t}+\beta_{2} \Delta \text { Income }_{i t}+\Delta Z_{i t} \gamma+\Delta \xi_{i t}
$$

Municipality specific fixed effects are eliminated by transforming the regressors by first differencing, since it is a time-invariant factor. After first differencing equation (3), we get;

$$
\Delta \xi_{i t}=\Delta u_{i}+\Delta \varepsilon_{i t}
$$

or

$$
\xi_{i t}-\xi_{i t-1}=\left(u_{i}-u_{i}\right)+\left(\varepsilon_{i t}-\varepsilon_{i t-1}\right)=\varepsilon_{i t}-\varepsilon_{i t-1}
$$

where $\Delta$ is a difference operator.

In order to address problem (3) above, which is autocorrelation issue, the firstdifferenced lagged-dependent variable (lag expenditure) is also instrumented with its past levels.

Table: 5

\begin{tabular}{|c|c|c|}
\hline $\begin{array}{l}\text { (1) } \\
\text { VARIABLES }\end{array}$ & $\begin{array}{l}\text { (2) } \\
\text { Exogenous }\end{array}$ & $\begin{array}{l}\text { (3) } \\
\text { Endogenous }\end{array}$ \\
\hline Grants & $\begin{array}{l}0,835^{* * * *} \\
(0,060)\end{array}$ & $\begin{array}{l}0,666^{* * *} \\
(0,328)\end{array}$ \\
\hline Income & $\begin{array}{l}0,651 * * * \\
(0,047)\end{array}$ & $\begin{array}{l}0,589^{*} \\
(0,345)\end{array}$ \\
\hline Lag population growth & $\begin{array}{l}97,815^{* * *} \\
(43,179)\end{array}$ & $\begin{array}{l}18,078 \\
(20,261)\end{array}$ \\
\hline Population & $\begin{array}{l}-0,000 \\
(0,000)\end{array}$ & $\begin{array}{l}-0,000 \\
(0,000)\end{array}$ \\
\hline Lag Expenditure & $\begin{array}{l}0,160 * * * * \\
(0,021)\end{array}$ & $\begin{array}{l}0,154^{* * * *} \\
(0,013)\end{array}$ \\
\hline $\begin{array}{l}\operatorname{AR}(1) \\
\operatorname{AR}(2)\end{array}$ & $\begin{array}{l}0,000 \\
0,000\end{array}$ & $\begin{array}{l}0,000 \\
0,690\end{array}$ \\
\hline $\begin{array}{l}\text { Sargan test of } \\
\text { over identification for the } \\
\text { exogenous instruments }\end{array}$ & 0,000 & 0,420 \\
\hline $\mathrm{T}$ test for Equality & $5,08 * *$ & $4,22 * *$ \\
\hline Observations & 2.503 & 2.503 \\
\hline Number of Municipalities & 838 & 838 \\
\hline
\end{tabular}

Difference GMM Estimation

(Dependent variable is expenditure per capita) 
$p<0.01, * * p<0.05, * p<0.1$, Figures in parenthesis are heteroskedasticity corrected standard errors. $T$ test for equality of grant and revenue coefficients shows that null hypothesis is rejected at $5 \%$ level.

Arellano-Bond estimator was designed for "small T, large N" panels, meaning small time periods and many cross-sectional units. A shock to the municipality fixed effect in large time dimensional panels, which appears in the error term, will drop over time. Equivalently, the correlation of the lagged-dependent variable and the error term will not be significant anymore (see Roodman, 2014).

We show the estimates of the difference GMM estimators' model specifications in Table 5. Column 2 presents the specification where all the explanatory variables are treated as exogenous while column 3 presents the estimates of the difference GMM estimator of model where Grants and Income variables are considered as potentially endogenous variables.

GMM estimators require two conditions to be consistent. First condition is that error term should not be serially correlated and second, the lagged values of the explanatory variables must be accurate as instruments. (Arellano and Bond, 1991) suggested the examination of serial correlation in the error term to deal with the first one. This test seeks the first and second order serial correlation in the residuals from the regression in differences. It is a common fact that the differenced error term exhibits first order serial correlation even if the residuals in levels are not correlated. However, second order serial correlation indicates that the moment conditions are valid producing consistent estimates.

We perform a Sargan test of over-identifying restrictions for the exogenous instruments. Sargan tests the null hypothesis of overall validity of the instruments. When this null hypothesis is rejected, the validity of instruments is approved. Sargan and AR tests are reported at third row from the bottom of Table 3. Tests in Column 2 provide the evidence of second-order serial correlation and the instruments are not exogenous. This is an expected result since we were suspicious about endogeneity in the beginning. However, when we estimate the model treating "Grant and Income variables" as endogenous (Column 3), we cannot reject the null hypothesis of no serial correlation at the $10 \%$ confidence level and it means that the instruments are not correlated with the error term. In addition to that, we also cannot reject the null hypothesis of instruments being exogenous at the $10 \%$ confidence level. Hence Column 3 in Table 3 enables us to use those results to conclude the model because it passes all the relevant tests. Table 3 shows the point estimates of regression based on our estimation strategy. However, we need to test formally the coefficients of grant and revenue variables in order to pass judgement on the flypaper effect exists in Turkey. Therefore we run a formal test for the hypothesis of $H_{0}: \beta_{1}=\beta_{2}$ against $H_{1}: \beta_{1}>\beta_{2}$ and report the results in Table 5. We find that we can reject the equality hypothesis at the $5 \%$ level. We argue that grants have more impact on expenditure than local revenues in municipality level.

Table 6 shows the logarithmic estimates of the same equation. When we compare Table 5 and Table 6, we see that the Fly paper effect still remains, and its magnitude 
increases. Table 6 also reveals that our conclusions are robust to different estimation methods. Although Becker (1996) argues that the flypaper effect is highly sensitive to the specification of the expenditure function since the linear and logarithmic equations presents different results in the paper. However, in our estimations even if we use linear and logarithmic form of the expenditure function, our conclusion does not change and not depend on the functional form.

\section{Table: 6}

Logarithmic Estimates of Variables in Table 2

(Dependent variable is log of expenditure per capita)

\begin{tabular}{|c|c|c|}
\hline VARIABLES & $\begin{array}{c}\text { (1) } \\
\text { Exogenous }\end{array}$ & $\begin{array}{c}(2) \\
\text { Endogenous } \\
\end{array}$ \\
\hline Grants & $\begin{array}{c}0,265 * * * \\
(0,027)\end{array}$ & $\begin{array}{c}0,442 * * * * \\
(0,070)\end{array}$ \\
\hline Income & $\begin{array}{c}0,293 * * * \\
(0,014)\end{array}$ & $\begin{array}{c}0,140^{* *} \\
(0,058)\end{array}$ \\
\hline Lag population growth & $\begin{array}{c}-1,808 * * * \\
(0,693)\end{array}$ & $\begin{array}{c}0,282 \\
(0,263)\end{array}$ \\
\hline Population & $\begin{array}{c}0,179 \\
(1,044)\end{array}$ & $\begin{array}{l}-0,793 \\
(0,482)\end{array}$ \\
\hline Lag Expenditure & $\begin{array}{c}0,047 \\
(0,085)\end{array}$ & $\begin{array}{c}0,145^{* * * *} \\
(0,048)\end{array}$ \\
\hline $\begin{array}{l}\mathrm{AR}(1) \\
\mathrm{AR}(2)\end{array}$ & $\begin{array}{l}0,000 \\
0,000\end{array}$ & $\begin{array}{l}0,000 \\
0,307\end{array}$ \\
\hline $\begin{array}{l}\text { Sargan test of } \\
\text { over identification for the } \\
\text { exogenous instruments } \\
\text { T test for Equality }\end{array}$ & 0,000 & $8,58^{* * * *}$ \\
\hline $\begin{array}{l}\text { Observations } \\
\text { Number of Municipalities }\end{array}$ & $\begin{array}{c}2.496 \\
837\end{array}$ & $\begin{array}{c}2.496 \\
837\end{array}$ \\
\hline
\end{tabular}

Notes: This table presents GMM regressions in logarithmic form with expenditure per capita as dependent variable. The independent variables of interest are grant and income variables. Sargan tests the null hypothesis of overall validity of the instruments. When this null hypothesis is rejected, the validity of instruments is approved. Significant levels $* * * p<0.01, * * p<0.05, * p<0.1$, Figures in parenthesis are heteroskedasticity corrected standard errors. $T$ test for equality of grant and revenue coefficients shows that null hypothesis is rejected at $1 \%$ level when grants and income variables are treated as endogenous.

The flypaper effect exists in Turkish local government finance and its magnitude is similar with the fixed effect estimation. This makes our analysis robust since our result holds even if the estimation strategy differs. Turkish municipalities also experience substitution effect of unconditional grants on the revenue collection efforts. In other words, grants transferred by central government to municipalities in Turkey, substitute local revenues leading lesser local tax effort.

\section{Conclusion}

In this paper, we investigate that the phenomenon of flypaper effect and its relation to the local tax effort, by using a panel data that consist of all province and district municipalities in Turkey between 1997 and 2005 excluding 1998 due to non-available fiscal data. The flypaper effect introduces the phenomenon of which an increase in the unconditional grants leads greater spending than equivalent increase in the local income. We use fixed effects and dynamic panel data specific GMM estimators to obtain the results. 
According to our estimations, the flypaper effect does exist for the Turkish municipalities. This result is robust to various model specifications and econometric techniques. Turkish municipalities also experience substitution effect of unconditional grants on the revenue collection efforts. In other words, grants transferred by central government to municipalities in Turkey, substitute local revenues leading lesser local tax effort.

Duncombe (1996) recommends that, if the flypaper effect exists, central government should develop a policy to predict funds required and assign unconditional grants accordingly. For instance, if local governments experiencing a budgetary gap are many, then there are two alternative options to improve the budget; either a reduction in grant or an increase in local taxes. In the flypaper theory, a reduction in grants would have more impact in lowering a budgetary gap than an increase in local taxes, because expenditures are increased by unconditional grants more than equivalent increased in private income. This fact explains that governments might use grants to affect local budget to reduce municipality spending. From the political perspective, politicians who are aligned with the same political party in the municipality could assure more grants to be transferred to his/her jurisdiction when the elections are close so that the municipality provides more public good and influence the voters. By doing so, politicians might increase their probability of re-elected in the next election.

\section{References}

Acosta, P. (2010), “The 'Flypaper Effect' in Presence of Spatial Interdependence: Evidence from Argentinean Municipalities", The Annals of Regional Science, 44(3), 453-466.

Allers, M. \& W. Vermeulen (2016), "Capitalization of Equalizing Grants and the Flypaper Effect", Regional Science and Urban Economics, 58, 115-129.

Arellano, M. \& S. Bond (1991), "Some Tests of Specification for Panel Data: Monte Carlo Evidence and An Application to Employment Equations", The Review of Economic Studies, 58, 277-297.

Bailey, S.J. \& S. Connolly (1998), “The Flypaper Effect: Identifying Areas For Further Research”, Public Choice, 95(3-4), 335-361.

Becker, E. (1996), “The Illusion of Fiscal Illusion: Unsticking the Flypaper Effect”, Public Choice, 86(1-2), 85-102.

Case, A.C. \& H.S. Rosen \& J.R. Hines Jr (1993), "Budget Spillovers and Fiscal Policy Interdependence: Evidence from the States", Journal of Public Economics, 52(3), 285307.

Courant, P.N. \& E.M. Gramlich \& D.L. Rubinfeld (1978), The Stimulative Effects of Intergovernmental Grants: or Why Money Sticks Where It Hits, University of Michigan, Institute of Public Policy Studies.

Cárdenas, O.J. \& A. Sharma (2011), "Mexican Municipalities And The Flypaper Effect”, Public Budgeting \& Finance, 31(3), 73-93.

Doğan, M. \& A.İ. Baş (2013), "Bir Finansman Kaynağı Olarak Belediyelerde Borçlanma", Marmara University Journal of Economic \& Administrative Sciences, 34(1), 293-315.

Duncombe, W. (1996), "Public Expenditure Research: What Have We Learned?", Public Budgeting \& Finance, 16(2), 26-58. 
Fisher, R.C. (1982), "Income and Grant Effects on Local Expenditure: The Flypaper Effect and Other Difficulties", Journal of Urban Economics, 12(3), 324-345.

Gramlich, E.M. \& H. Galper \& S. Goldfeld \& M. Mcguire (1973), "State and Local Fiscal Behavior and Federal Grant Policy", Brookings Papers on Economic Activity, 1, 15-65.

Holtz-Eakin, D. \& W. Newey \& H.S. Rosen (1988), "Estimating Vector Autoregressions with Panel Data", Econometrica: Journal of the Econometric Society, 56(6), 1371-1395.

Knight, B. (2002), "Endogenous Federal Grants and Crowd-Out of State Government Spending: Theory and Evidence from the Federal Highway Aid Program", American Economic Review, 92(1), 71-92.

Niskanen, W.A. (1968), “The Peculiar Economics of Bureaucracy”, The American Economic Review, 58(2), 293-305.

Pevcin, P. (2011), "Fly-Paper Effect in Slovenian Municipal Finances", Hrvatska I Komparativna Javna Uprava, 11, 707-728.

Roodman, D. (2014), Xtabond2: Stata Module To Extend Xtabond Dynamic Panel Data Estimator, Statistical Software Components.

Sagbas, I. \& N.T. Saruc (2008), "The Surge Impact of the Flypaper, Substitution and Stimulation Effect on Local Tax Effort in Turkey", International Research Journal of Finance and Economics, 13, 42-49.

Sagbas, I. \& N.T. Saruc (2004), "Intergovernmental Transfers and the Flypaper Effect in Turkey", Turkish Studies, 5(2), 79-92.

Schwallie, D.P. (1989), "Measuring the Effects of Federal Grants-In-Aid on Total Public Sector Size", Public Finance Review, 17(2), 185-203.

Turnbull, G.K. (1998), "The Overspending and Flypaper Effects of Fiscal Illusion: Theory and Empirical Evidence", Journal of Urban Economics, 44(1), 1-26.

Vigneault, M.L. (2005), Intergovernmental fiscal relations and the soft budget constraint problem, Institute of Intergovernmental Relations.

Worldbank (2004), Municipal Sector Review, Worldbank.

Worthington, A.C. \& B.E. Dollery (1999), "Fiscal Illusion and the Australian Local Government Grants Process: How Sticky is the Flypaper Effect?", Public Choice, 99(1-2), 1-13.

Wyckoff, P.G. (1988), “A Bureaucratic Theory of Flypaper Effects”, Journal of Urban Economics, 23(1), 115-129. 